\title{
Perceived use of accounting information and practices of accounting in micro enterprises of developing countries
}

\author{
Md. Zakir Hosen ${ }^{1, a}$, Md. Takibur Rahman ${ }^{\mathrm{a}}$ and \\ Md. Mamun ur Rashid ${ }^{\mathrm{b}}$ \\ ${ }^{a}$ Department of Accounting and Information Systems, Patuakhali Science \\ and Technology University, Bangladesh \\ ${ }^{b}$ Department of Agricultural Extension and Rural Development, Patuakhali \\ Science and Technology University, Bangladesh
}

\begin{abstract}
Research question: What is the perceived use of accounting information and current practices of accounting in micro enterprises?

Motivation: Business decisions are more accurate and focused if they are made based on reliable information, for instance, accounting information. However, the use of accounting information in decision-making varies among the business entities, which is even poor in micro enterprises in developing countries.

Idea: This study aims to examine perceived use of accounting information in decisionmaking and current practices of accounting in micro enterprises of Bangladesh.

Data: The data include the characteristics of owner and business, perception on accounting systems, the use of accounting information (ACI) in decision-making and the current accounting practices collected from 148 respondents.

Tools: The data are analyzed using standard descriptive statistical tools and multivariate regression.

Findings: We find that the perception regarding the use of ACI in decision-making is low. Furthermore, the existing practices of accounting in surveyed entities are very low. The key practices, in terms of weighted mean, are cash reconciliation and practices of budgeting. Furthermore, the number of employees in the enterprises has a positive significant relationship with the perception regarding the use of ACI in decision-making. Besides, enterprises practicing accounting have higher performance. In addition, the size, and the nature of business have statistically significant positive effects on turnover.
\end{abstract}

\footnotetext{
${ }^{1}$ Corresponding author: Department of Accounting and Information Systems, Faculty of Business Administration and Management, Patuakhali Science and Technology University, Patuakhali-8602, Bangladesh, Cell: +88-01714209306, Email: zakir@pstu.ac.bd.
} 
Contribution: This study may help stakeholders in understanding the role of accounting in business decision-making and its impacts on financial performance of the micro enterprises in developing countries.

Keywords: accounting information; decision-making; perception; proprietorship.

JEL codes: M41, M48, G21

\section{Introduction}

Micro Enterprises (MEs'), a segment of broadly defined small and medium size enterprises (SMEs), accelerates economic growth of a country and protect economic and social well-being even at times of economic emergencies like the ongoing Covid-19 pandemic. Moreover, these enterprises exist almost in every country and play a pivotal role in advancing the economy providing employment, innovations, available affordable products (services), and revenues (Albu et al., 2016; Blackburn \& Javris, 2010). MEs are usually owned, managed and controlled by family with unlimited obligations and may occasionally be organized in pursuit of non-financial objectives like work life balance (Blackburn \& Jarvis, 2010; Heibl, 2013; Songini et al., 2013; Stone, 2011). Moreover, entrepreneurs prefer SMEs because of easiness to start, manage, operate, and control with very few applicable statutory regulations including financial reporting in most developing and underdeveloped countries in Asia and Africa.

Good accounting practices at the enterprise level, irrespective of size, scale and nature of the business, serve as a source of information to the stakeholders. This information signals if enterprises are capable of achieving the desired results, if not, what should be done in the future. It means that business decisions are more focused and efficient if decisions are based on reliable information. Accounting system can be helpful in this regard (Carey, 2015). However, the extent of practices and the use of such system of generating information vary among economies, enterprises, businesses. Unlike their counterparts in developing countries, SMEs in developed countries like Australia most often depend on external accountants' advices which results in improved performance (Carey, 2015; Venter et al., 2018). This can be attributed to the higher regulatory requirements prevailed in those countries. However, the practices of accounting are much less prevalent in developing countries of Africa and Asia due to lack of knowledge, applicable accounting standards, and capabilities of implementing enterprises (Mendoza, 2014; Ndiaye et al., 2018; Orobia et al., 2020). Hence, the business decisions mostly based on ad hoc basis because these enterprises do not manage information systems that provide reliable information. In addition, they have very poor control on the business 
activities (Ismail \& King, 2005). Furthermore, Andrianaivo et al. (2018), Padachi (2012) and the SME policy 2019 of Bangladesh highlighted that most SMEs are not able to manage required institutional financing due to the lack of documents supporting its credit worthiness. On the other hand, lack of formal financing is considered as one of the main constraints to the growth of SMEs in developing and underdeveloped countries.

However, SMEs in developing countries most often follow the basic accounting structure of recording business transactions. For instance, Uddin et al. (2017) found that only $20 \%$ of small enterprises used accounting system in Bangladesh. This study however, does not provide any clear evidence as to what extent this $20 \%$ is practicing accounting system. This low practice may be due to the narrow perception of ownermanagers, poor technical knowledge on accounting; assuming that accountants just count the numbers only (Lucas et al., 2013; Mbroh \& Assah, 2015). Besides, direct involvement of owners to oversee the operation, learning-by-doing management philosophy and strong owner-manager relationship may also discourage to use formal accounting and reporting systems (Albu et al., 2016; Stone, 2011). It indicates that the perceived use of accounting information and practices of accounting may be even poor in micro enterprises in developing economies.

On the other hand, earlier studies such as Akanbi et al. (2017), Mbroh and Assah (2015), and Maseko and Manyani (2011) found that the use of accounting information is higher in SMEs where the owners and managers have knowledge on accounting and have positive perception on the use of accounting systems. Similarly, Ezejiofor and Olise (2014) argued that the practices of accounting can significantly contribute to the performance of small-scale business by providing information for more efficient planning, controlling and monitoring of the regular operations of the business (Grazia-Oana, 2012). The Okoli (2011) study argued that adequate record keeping could improve the profitability and continuity of small-scale enterprises as well, since it helps the proprietors to keep in track of the performance of these enterprises. However, the same study asserted that, the small-scale operators could not assess their performances effectively due to inadequate record keeping. It is thus, imperative to investigate the extent of accounting practices and its intended use in the case of micro enterprises. The findings may guide future policies supporting the growth of this sector from a developing country perspective.

Therefore, the objectives of this study are to examine (i) the perceived use of accounting information by micro enterprises in Bangladesh and its determinants; (ii) the extent of current practices of accounting; and (iii) the impact of accounting practices on business performance.

This study may help the policymakers to identify areas requiring improvements for the extended use of accounting information systems in micro enterprises, which, in turn, will guide future policies addressing issues, such as documentation, easing 
access to finance and revenue collection from these growing enterprises. This study has taken Bangladesh as the case study to make the study more representative to the most of the developing economies.

The study is structured as follows: section two provides a literature review followed by SME sector in Bangladesh in section three. The methodology is described in section four. Section five reports the results of the analysis. Finally, section six concludes the paper.

\section{Literature review}

The Small and Medium Enterprises (SMEs') are mainly sole proprietorship, which means that it is a standalone one-person owned business and can be operated only with a trade license from the regulatory authority. Sole proprietorship enterprise does not have legal status (Ndiaye et al., 2018) indicating that it is inseparable from its owner, and it cannot sue or be sued (Obasan et al., 2016). Theoretically, business transactions should be kept separate from the personal transactions to assess the business performance accurately. However, in practice owners' personal transactions are mixed up with business transaction due to its management pattern and lack of knowledge on the benefits of keeping it aside.

Many MEs around the world fail within the first few years of its operation (Orobia et al., 2020; Soininen et al., 2012) owing to the lack of ability to follow through market dynamics, follow up actions, and inflexibility in decision-making. Moreover, inappropriate decision-making based on incorrect and informally maintained financial information is also one of the primary reasons of their failure (Orobia et al., 2020). Most owner-managers do not have sufficient knowledge on accounting, its importance in decision-making, and the way to maintain accounting system.

The use of accounting information systems internally or external accounting advisory services (outsourcing) for reliable financial information may help improving this situation of small business enterprises (ICAEW, 2014; Venter et al., 2018). Venter et al. (2018) indicated that the SMEs in developed countries usually purchase professional accounting services from external professional accounting firms. However, both of these options are costlier to the micro entrepreneurs. This has been identified as the reason for lack of practicing accounting at enterprise level (Andrianaivo et al., 2018) in developing countries. It is also found that most micro enterprises in developing and underdeveloped economies cannot secure sufficient institutional financing (Ndiaye et al., 2018) due to the lack of documents supporting the assessment of the financial health of the enterprise by the lenders (Aziz \& Siddique, 2016; Jesmin, 2009). Therefore, it is important for micro enterprises to maintain proper records of its economic activities allowing generation of reliable information. This implies that accounting system enables doing the things right and 
doing the right things. It is because, accounting, as defined in the literature, refers to the identification, measurement, and communication of financial information to the interested persons (Kieso et al., 2011), whereas, accounting systems generates statements that provide information to the stakeholders for decision-making.

Effective and efficient accounting information systems are the most adapting and self-regulating instrument in a dynamic environment, which aids in decisionmaking, irrespective of the size of the organization, areas of operation, and ownership structure (Collier, 2015; Royaee et al., 2012; Siyanbola, 2012). It is because the accounting system keeps all the financial information in a systematic way and presents relevant statements, namely balance sheet (financial position), income statement (results of the business), retained earnings statement (status of ownership) and statement of cash flows (status of cash) following a uniform framework. These statements help measuring financial performance and support decisions making for the future (Ismail et al., 2003). Thus, the system enables management, i.e. owners in case of small businesses to evaluate and select most profitable alternative among a set of alternatives to achieve desired results and follow up actions (Drucker, 2010) by providing the necessary financial information (Grazia-Oana, 2012).

Furthermore, MEs' decision-making processes are not commonly goal-oriented, and planned (Child \& Hsieh, 2014). Moreover, most MEs' decisions come up from owner's whim and spontaneous actions based on little information (Albu et al., 2016), which do not provide sufficient ground for making improved decisions by the Stakeholder (i.e. employees, customers, suppliers, investors, and government) (Amaoko, 2013). It means that most often the micro enterprises do not use accounting information in making future decisions, monitoring and controlling the business activities.

On the other hand, the practices of accounting information system to generate financial information are influenced largely by perception, experience, education qualification of owners-managers (Kahsay \& Zeleke, 2019), facilitating condition, time, and cost of maintaining the system (Seman et al., 2019). The other factors, which influence the use of financial information in decision-making, are ownership and management style, cost of generating decision related information, availability of resource (Albu et al., 2013), size and age of the business, (Lalin \& Sabir, 2004) and involvement of the business in the society. Similarly, Albu et al. (2016) found that perception towards accounting system, the volume of business, age, competition, legal requirements, non-agency relationship, and resources influence the use of accounting information in decision-making (Blackburn et. al., 2018).

Perception defines personality traits that may influence the extent of accounting practices and its use in decision-making. Many studies used demographic and economic aspects of an individual in defining personality traits. However, Devi and 
Samujh (2010) included whim of owner or manager, accustom, motives, preferences, needs, practice, confidence, expectation, attitude and mental setup in defining personality traits. Whereas individual's background and length of business are included in the study of Alam and Nandan (2010). Further, culture and society are considered in defining the personality traits in the study of Kahsay and Zeleke (2019), Seman et al. (2019) and Lalin and Sabir (2010).

The lack of technical knowledge on accounting internal to the enterprise can alternatively be solved by outsourcing accounting services from professional accounting firms (Blackburn et al., 2014). However, enterprises in the developing countries mostly depend on advice from friends and family instead of this alternative due to the higher costs, do-it-yourself philosophy, and lack of knowledge on sourcing this advice, etc. (Blackburn \& Jarvis, 2010; Sawers \& Whiting, 2010).

Following the literatures and taking the existing SMEs business environment in Bangladesh into account, this study has considered characteristics of owner and business as explanatory variables influencing the perception of accounting practices and the use of accounting information in decision-making. This study has used 11 close-ended questions in determining the perception on accounting information systems and 18 closed ended questions to identify the use of accounting information systems in decision-making. Furthermore, the study has used 18 close-ended questions to understand the extent of current practices of accounting tools by the selected enterprises.

\section{Small and Medium Enterprises (SMEs) sector in Bangladesh}

The SME sector, which supply almost half of the global private sector's output and provide 63\% jobs globally (ICAEW, 2014; Ndiaye et al., 2018), has been experiencing spectacular growth both in developed and developing countries. SMEs, on aggregate, constitute a major part of businesses in Bangladesh and play an important role in the growth of the economy. The sector contributes $25 \%$ of GDP of the country and $87 \%$ to the private sector employment. Bangladesh National Industrial Policy (NIP) 2016 has classified all the enterprises operating under this sector as micro, small and medium enterprises based on the number of the employed workforces as well as the value of the fixed assets under control. The classification based on number of employees is given in Table 1.

The majority of all non-farm enterprises of SMEs' are the micro and small enterprises, providing employment to 20.3 million non-agricultural workforces in Bangladesh. Thus, the success of Bangladesh's rapid transition to the middle-income country status depends considerably on the measures taken for more inclusive growth of SMEs. It is because, these enterprises play a dominating role to the 
industrial growth (Ademola et al., 2012) by providing services at the up and down streams of the value chain to larger corporations that could otherwise be managed at a higher cost. Almost $85 \%$ of SMEs are sole proprietorship in Bangladesh of which $65 \%$ have legal status (Uddin et al., 2017). The sole proprietors enjoy all profits and bear all business losses, debts and make decisions as well (Dlabay et al., 2016).

Table 1. SMEs classification based on numbers of employees

\begin{tabular}{lll}
\hline Categories & Nature of Business & Employed manpower \\
\hline \multirow{2}{*}{ Micro Enterprises (ME) } & Manufacturing & $10-24$ \\
& Trading & Less than 10 \\
& Services & Less than 5 \\
\hline \multirow{3}{*}{ Small } & Manufacturing & $25-99$ \\
& Trading & $6-10$ \\
& Services & $10-49$ \\
\hline \multirow{2}{*}{ Medium } & Manufacturing & $100-150$ \\
& Trading & $11-50$ \\
& Services & $50-100$ \\
\hline
\end{tabular}

However, this sector faces several challenges that hinder their development opportunities, such as poor managerial skills, unqualified labor, borrowings at higher interest rates, and reduced access to finance due to information asymmetry. Furthermore, a large proportion of small and micro-businesses remains in the informal sector and lacks accounting records. Nevertheless, practices of accounting and reporting can play important role in supporting MEs development by mitigating many of these challenges including information asymmetry, high interest rates, and access to finance. It is because, MEs can access to finance and at a lower interest rate if lenders have required and reliable information to assess risks, liquidity, and profitability of enterprises. In addition, accounting systems supports the management to make efficient decisions by allocating resources to more profitable use, determining the amount of financing required.

One of the reasons for the lack of accounting records and its use in MEs' is due to the perception that they needless accounting information, since the owner is personally involved in managing the business activities (Asaduzzaman, 2016). However, such assertion is not realistic, especially when they look for external finance, it is harder for the MEs to access institutional finances without required financial information (William, 2008). Furthermore, Mitchel et al. (2000) argued that accounting information supports monitoring and controlling activities of the business by providing information on costing, expenditure, and cash flow. However, most MEs' lack reliable accounting information, and control systems that facilitate efficient decision-making (Peren \& Grant, 2000). Nevertheless, accounting is recognized as a tool for profit planning and assembling financial information in a way that might help management in informed judgment and decision-making (Copeland \& Dascher, 1978). 
The increasing contribution of SME sector globally and nationally motivated policymakers to make timely policies focusing on SMEs, as an important instrument of private-sector development to support entry, participation and survival in global markets. For instance, the purposes of the latest SME policy 2019 of Bangladesh are to ease the access to finance, market, education and training, technology, innovation, business support services, and information for these enterprises. These have a direct link with the current level of accounting practices and with how the decisions are made at the enterprise level. It is to be noted that the quality of financial statements is positively associated with the access to finance and negatively with information asymmetry (Nanyondo et al., 2013).

In addition, there is an established accounting and reporting standard for these enterprises to generate reliable and comparable financial information, which is essential for sustainable and inclusive growth of this sector. The existing BFRS (Bangladesh Financial Reporting Standard) is mainly focused on SMEs. Unfortunately; there is no standardized framework or guidelines in the existing standard specific to micro enterprises (MEs) in Bangladesh.

Overall, the perception of using accounting for record keeping, decision-making, and performance measurement seems to be insufficient. Besides, the current practices of accounting may not be desirable due to the lack of motivation, knowledge, skills, organizational capacity, frameworks, guidelines, and regulations. Therefore, this study aims at investigating overall scenarios of Micro enterprises of developing countries in terms of its perception of using accounting, current practices, and impacts of these on enterprises performances.

\section{Data and methodology}

\subsection{Data}

We collected data from 148 micro enterprises operating in three selected Upazilas (Sub-districts) under Barishal and Patuakhali districts (administrative areas) of Bangladesh using structured interview. Trained undergraduate business students with accounting background conducted the interviews. The structured interview is also known as a standardized interview or a researcher-administered survey, which, consists of a series of questions designed to bring specific response or answer from respondents (Phellas et al., 2011). The questions are normally specific and always offer a fixed range of answers, relatively quick and easy to administer. The advantage of this type of interview is that the questions are presented identically or in similar order in each session of interview and to each respondent, making the data analysis easier and focused on the research objective(s). 
The majority of the questions in the interview were close-ended. Among 170 contacted respondents, 148 responded affirmatively for the interview. Among the completed interview, 43 responses were dropped due to inconsistency in responses. This leaves us with 105 interviews for this study. We selected respondents randomly based on their location, willingness to participate in the interview and business characteristics.

The interview consisted of four sections: the first section included demographic information of the respondents, such as the position of the respondent in the enterprises, year in the operation of the business, education level of the respondents, types of businesses, number of employees, and number of outlets. The second section included 11 questions related to the owner's perception towards using ACI in business decision-making which were evaluated based on five-point Likert scale having categories, namely strongly disagree ( -2 points); disagree (-1 point); neither agree nor disagree ( 0 point); agree (1 point); strongly agree ( 2 points). It is important to note that questions related to perception were formulated both in positive and negative form to secure accurate information. For negative statements, the scoring categories were reverse to the positive statements. The third section consisted of 18 questions related to the use of accounting information in business decision-making, which were measured based on a five point rating scale, such as always (4 point); frequently ( 3 points); occasionally ( 2 points); rarely ( 1 points); and never ( 0 point). The fourth section consisted of 18 questions related to the current accounting practices, which were rated same as third section. The summary of the variables and information generated from the survey is exhibited in Table 2 .

Table 2. Descriptive statistics of variables of this study

\begin{tabular}{|c|c|c|c|c|c|}
\hline \multicolumn{2}{|c|}{ Variables } & \multirow[t]{2}{*}{ Mean } & \multirow[t]{2}{*}{ Std. } & \multirow[t]{2}{*}{ Min } & Max \\
\hline \multicolumn{3}{|l|}{ Dependent variables: } & & & \\
\hline Education (Edu.) & Years & 11 & 3 & 1 & 17 \\
\hline No. Of Employees (NoE) & $\begin{array}{l}\text { Numbers employees in } \\
\text { services }\end{array}$ & 4 & 4 & 0 & 30 \\
\hline Experience (Exp.) & Years & 12 & 12 & 1 & 12 \\
\hline \multirow{3}{*}{ Nature of business: } & 1 if merchandising $(82 \%)$ & 0.83 & 0.38 & & \\
\hline & 2 if service $(4 \%)$ & 0 & 0 & 1 & 3 \\
\hline & 3 if manufacturing (14\%) & 0.12 & 0.33 & & \\
\hline \multirow{6}{*}{$\begin{array}{l}\text { Extent of Accounting practice } \\
\text { (AccP) \& use in decision- } \\
\text { making: (Measured based on } \\
18 \text { statements) }\end{array}$} & 0 if never & & & & \\
\hline & 1 if rarely & & & & \\
\hline & 2 if occasionally & 20 & 10 & 3 & 40 \\
\hline & 3 if frequently & & & & \\
\hline & 4 if always & & & & \\
\hline & 0 if neither agree or disagr & 6 & 7 & -22 & 17 \\
\hline
\end{tabular}


Perceived use of accounting information

and practices of accounting in micro enterprises of developing countries

\begin{tabular}{|c|c|c|c|c|c|}
\hline \multicolumn{2}{|c|}{ Variables } & \multirow[t]{2}{*}{ Mean } & \multirow[t]{2}{*}{ Std. } & \multirow[t]{2}{*}{ Min } & \multirow[t]{2}{*}{ Max } \\
\hline $\begin{array}{l}\text { Perception on using ACI in } \\
\text { decision-making (PACI): } \\
\text { (Measured based on } 11 \\
\text { statements) }\end{array}$ & $\begin{array}{l}1 \text { if agree } \\
(-1) \text { if disagree } \\
2 \text { if strongly agree } \\
(-2) \text { if strongly disagree }\end{array}$ & & & & \\
\hline \multicolumn{6}{|l|}{ Independent variables: } \\
\hline Turnover ('000) & in USD (84.98 BDT = 1 USD) & 213 & 246 & 140 & 2000 \\
\hline $\begin{array}{l}\text { Use of ACI in decision-making } \\
\text { (ACIDM): (Measured based on } \\
18 \text { statements) }\end{array}$ & $\begin{array}{l}0 \text { if used never } \\
1 \text { if used rarely } \\
2 \text { if used occasionally } \\
3 \text { if used frequently } \\
4 \text { if used always }\end{array}$ & 22 & 11 & 3 & 40 \\
\hline
\end{tabular}

It is worth mentioning that before finalizing the interview schedule, the reliability of the instruments was tested through test-retest method using 20 samples. We found a significant positive correlation between two tests, which confirmed the reliability of the instrument. The paper used Variance Inflation Factor (VIF), Residual Statistics, Density Plot, and Scatter Plot to identify possible collinearity and inconsistency in the data.

\subsection{Analytical method}

The cleaned data at first were analyzed using descriptive statistics, such as percentage, mean, standard deviation, and range to identify the current practices of accounting, and perception of the use of accounting information. Subsequently, the data were analyzed applying multiple regression, two-way ANOVA, and principal component regression to examine (i) the determinants of the use of ACI in business decision-making, and interaction among the variables; and (ii) impacts of accounting practices and enterprise characteristics on performance respectively.

There are different models that can be used, for instance, when the dependent variable is continuous, the linear regression is feasible if there is only one independent variable. However, if there are more than one independent variables, multiple regression could be an option, though Tobit model is the better option when the dependent variable is truncated. In this study, multiple regression is preferred since there is one dependent variable and are continuous but not truncated with several independent variables.

Two multiple regression models were used, the first one was estimated for examining the relationship between enterprise performance and accounting practices, and the second one was carried out to identify the determinants of the use of ACI in decisionmaking. 
The general form of multiple linear regression model following the classical structure can be written as:

$$
Y_{i}=\beta_{0}+\sum_{i}^{k} \beta_{i j} X_{i j}+\varepsilon_{i} \quad \text { Eq. (1) }
$$

where, $Y_{i}$ is the dependent variable, $X_{i j}$ are the independent variables, $\beta_{0}$ is the intercept, $\beta_{i j}$ are the parameters, and $\varepsilon_{i}$ are the error terms.

Thus, the empirical model based on Eq. (1) identifying determinants of ACI in business was specified as follows:

$$
\begin{gathered}
\operatorname{ACIDM}_{\mathrm{i}}=\beta_{0}+\beta_{1} \text { (No. of employees) }+\beta_{2} \text { (length of Business) }+\beta_{3}(\mathrm{PACI}) \\
+\varepsilon_{\mathrm{i}}
\end{gathered}
$$

where, $\mathrm{ACIDM}_{\mathrm{i}}$ is the dependent variable indicating the use of ACI for decisionmaking, $\beta_{0}$ is the intercept, $\beta_{i j}$ are the parameters to be estimated and $\varepsilon_{i}$ are the error terms.

Furthermore, to explore the interaction effect of independent variables, this research adopted fixed factors and fixed effects factorial ANOVA. Factorial design provides an opportunity to study the interaction effect of two treatment variables (Faraway, 2002, p. 180).

Therefore, in this study, two factors were 'number of employees' and 'perception on using ACI in decision-making'. This study assumes that, there are effects of independent variables (the number of employees and perception regarding use of $\mathrm{ACI}$ ) and their interaction on the expected outcomes (on the use of ACI in decisionmaking). The general structure for factorial experiment with factor ' $A$ ' (number of employees) at levels ' $\mathrm{a}$ ' and factor ' $\mathrm{B}$ ' (perception on use of ACI in decisionmaking) at levels ' $b$ ' can be written as:

$$
\mathrm{Y}_{\mathrm{ij}}=\mu+\tau_{\mathrm{i}}+\beta_{\mathrm{j}}+\gamma_{\mathrm{ij}}+\varepsilon_{\mathrm{ijk}}
$$

where,

$$
\begin{aligned}
& i=1,2,3, \ldots \ldots \ldots, a \\
& j=1,2,3, \ldots \ldots ., b
\end{aligned}
$$

$k=1,2,3, \ldots \ldots \ldots, r Y_{i j}$ is the expected outcome $\mu$ is the overall mean response, $\tau_{i}$ is the effect due to the $\mathrm{i}$-th level of factor A (number of employees). The $\beta_{j}$ is the effect due to the $\mathrm{j}$-th level of factor $\mathrm{B}$ (perception in using ACI for business decision- 
making) and $\gamma_{i j}$ is the effect due to any interaction between the $\mathrm{i}$-th level of $\mathrm{A}$ and the $j$-th level of B (i.e., between number of employees and perception of using ACI).

The total (corrected) sum of squares was derived as follows, where, $A B$ is the interaction between factor A and factor B (see, Lind et al., (2010) for the formulas for sum of squares) and summary is in Table 3.

$$
\mathrm{SS}(\text { Total })=\mathrm{SS}(\mathrm{A})+\mathrm{SS}(\mathrm{B})+\mathrm{SS}(\mathrm{AB})+\mathrm{SS}(\mathrm{E})
$$

Table 3. Summary of ANOVA including interaction between number of employees and perception on the use of $\mathrm{ACI}$ in decision-making (i.e., the ANOVA table for $a \times b$ factorial)

\begin{tabular}{|c|c|c|c|c|}
\hline Source & $\begin{array}{c}\text { Sum of } \\
\text { squares (SS) }\end{array}$ & $\begin{array}{c}\text { Degree of } \\
\text { freedom }(\mathrm{df})\end{array}$ & $\begin{array}{c}\text { Mean Squares } \\
\text { (MS) }\end{array}$ & $\mathbf{F}$ \\
\hline No. of employees & $\mathrm{SS}(\mathrm{A})$ & $(a-1)$ & $\mathrm{SS}(\mathrm{A}) /(\mathrm{a}-1)$ & $\mathrm{MS}(\mathrm{A}) / \mathrm{MS}(\mathrm{E})$ \\
\hline PACI & $\mathrm{SS}(\mathrm{B})$ & (b-1) & $\mathrm{SS}(\mathrm{B}) /(\mathrm{b}-1)$ & $\operatorname{MS}(\mathrm{B}) / \mathrm{MS}(\mathrm{E})$ \\
\hline Interaction & $\mathrm{SS}(\mathrm{AB})$ & $(a-1)(b-1)$ & $\mathrm{SS}(\mathrm{AB}) /[(\mathrm{a}-1)(\mathrm{b}-1)]$ & $\operatorname{MS}(\mathrm{AB}) / \mathrm{MS}(\mathrm{E})$ \\
\hline Error & $\mathrm{SS}(\mathrm{E})$ & $\left(\mathrm{N}^{*}-\mathrm{ab}\right)$ & $\mathrm{SSE} /(\mathrm{N}-\mathrm{ab})$ & \\
\hline Total (corrected) & SS (Total) & $(\mathrm{N}-1)$ & - & - \\
\hline
\end{tabular}

The 18 statements describing the extent of accounting practices are reduced to smaller numbers of factors (principal components) using principal component analysis. The extracted and grouped factors were subsequently used in multiple regression model for explaining relationship between accounting practices and enterprise performance. It is because the observed practices can be interpreted and empirically evaluated if data are grouped according to their relevance and purpose of use. This has been done based on latent root criterion (Eigen value $\geq 1$ ).

To ensure maximum independence of the resulting factors, the orthogonal (varimax) rotation extraction method was used. Missing responses have been replaced with mean values of obtained valid responses following Lien et al. (2006) and Flaten et al. (2005). The $\mathrm{KMO}^{\mathrm{i}}$ test was used to check the suitability of data for principal component analysis (PCA). A high KMO value (maximum 1.0) generally indicates that the PCA method is useful if the aim is to reduce the number of factors. In PCA analysis, components with factor loadings, which indicate the relationships of each variable with the underlying factors, greater than 0.40 may be considered as significant (Flaten et al., 2005).

Therefore, the empirical econometric model examining the relationship between accounting practices and business performance is specified by the following equation. 


$$
\begin{aligned}
& \mathrm{AccP}_{\mathrm{i}}=\alpha_{0}+\alpha_{1} \text { (No. of employees) }+\alpha_{2} \text { (Length of Business) }+\alpha_{3} \text { (PACI) } \\
& +\alpha_{\mathrm{i}} \text { Comp }_{\mathrm{i}}+\varepsilon_{\mathrm{i}} \quad \text { Eq. (5) }
\end{aligned}
$$

where, $A c c \mathrm{P}_{\mathrm{i}}$ is the extent of accounting practices by $\mathrm{i}^{\text {th }}$ enterprise, $\alpha_{0}$ is the intercept and $\alpha_{\mathrm{i}}$ is the coefficients to be estimated. The Comp $\mathrm{p}_{\mathrm{i}}^{\prime} \mathrm{s}$ are the principal components obtained from PCA.

\section{Results and discussion}

This section describes the results of this study. First, we interpret the descriptive statistics of the variables, perception, and use of ACI in business decision-making. In addition, this section also discusses the determinants of using ACI for business decision-making and status of current accounting practices and factors influencing the extent of practices as well.

\subsection{Descriptive characteristics of the respondents}

Data reported in Table 2 shows that the majority (36\%) of the enterprises have1402000 thousand USD annual sales and more than half $(57 \%)$ of the proprietors have education up to post graduation level. The nature of the organizations considered in this research is predominantly (85\%) merchandising and most of the respondents $(80 \%)$ are the owner of the enterprises. The average number of employees per enterprise is about 4, the average numbers of years in business is 12 years. However, details of each variable of the study are displayed in Table 2 .

\subsection{Perception and use of ACI for business decision}

The descriptive statistics of perception and use of ACI for business decision-making is arranged in Table 4 . The first row of the Table 4 shows that the respondents have low positive perception in using ACI for business decision-making. This finding to some extent confirms the Iranian managers' perceptions to use accounting information in decision-making process i.e. financial management, investment, organizational growth, and performance evaluation (Botchway \& Rashedi, 2018). Amoako (2013) also asserted that $64.76 \%$ of the 210 sampled Ghanaian respondents do not maintain accounting records. The low perception in this study may be due to inadequate educational qualification, misconception about competition, inadequate understanding of ACI usefulness in decision-making, notional regulatory requirements, etc. The second row shows that the present status of use of ACI for business decision-making is also low with a mean score 20.90 and standard deviation 10.22, which is consistent with the Keynesian study (Muteti et al., 2018). This low use of ACI for decision-making can be attributed to inadequate formal knowledge, poor competence, cost and time constraints to produce information, absence of adequate regulatory requirements, and lack of training on using ACI in decision- 
making. Ismail \& King (2005) also found that the most SMEs in which MEs belong to make business decision on off-the-cuff basis.

Table 4. Descriptive statistics of the respondent's perception and use of ACI $(n=105)$

\begin{tabular}{llcccr}
\hline SL & Variable & Mean & SD & PR & OR \\
\hline 1. & Perception regarding the use of ACI & 8.58 & 4.56 & -22 to 22 & -14 to 17 \\
2. & Use of ACI for decision-making & 20.90 & 10.22 & 0 to 72 & 3 to 55 \\
\hline
\end{tabular}

Note: $\mathrm{ACI}=$ Accounting Information; $\mathrm{PR}=$ Possible range; $\mathrm{OR}=$ Observed range

\subsection{Determinants of ACI use}

The study used regression analysis to identify the determinants of ACI use in decision-making. Before conducting regression analysis, suitability of the data has been evaluated and the results are displayed at the bottom of Table 5. The regression results in Table 5 show that three predictor variables, such as Perception of ACI use, number of employees, and longevity or age of business generated a significant model $\left(\mathrm{F}_{3,96}=20.177 ; \mathrm{P}<.000\right)$ and can jointly explain $36.8 \%$ variation in the use of financial information in business decision-making. Figures in Table 4 also indicate that the number of employees have the highest effect on using financial information in decision-making $(\beta=0.1 .667, \mathrm{P}<0.000)$ followed by perception of ACI use $(\beta=0.960, \mathrm{P} \leq 0.000)$.

However, the age of business don't have significant effect on the use of financial information in decision making, which conforms to the findings of Muteti et al., (2018) as they found that size of the business influenced the extent of accounting practices in SMEs. Further, this finding may differ from one country to another due to the lack of support from stakeholders, such as government, policy-makers, accounting bodies, and local organizations to improve accounting practices.

Table 5. Regression results showing determinants of ACI use in business decision-making $(n=104)$ (Eq. 2).

\begin{tabular}{|c|c|c|c|c|c|c|}
\hline SL Predictor value & B & SE & Beta & t-value & P Value & VIF \\
\hline 1. Number of employees & 1.667 & 0.305 & 0.442 & 5.461 & 0.000 & 1.026 \\
\hline 2. Length of business & -0.066 & 0.123 & -0.044 & -0.538 & 0.592 & 1.033 \\
\hline $\begin{array}{l}\text { 3. Perception regarding use of ACI } \\
\text { (PACI)* }\end{array}$ & 0.960 & 0.180 & 0.428 & 5.335 & 0.000 & 1.009 \\
\hline
\end{tabular}

Criterion variable: Use of ACI in business decision-making; $\mathrm{F}_{3,96}=20.177, \mathrm{P}<0.000$; $\mathrm{R}=62.2, \mathrm{R} 2=38.7$, adjusted $\mathrm{R}^{2}=36.8$; Cook's Distance $=0.000-0.138$; DurbinWatson=1.123, P>0.05.

The perception and the number of employees have significant influences on the use of accounting information in decision-making (Table 5). However, the age of business does not have any statistically significant influence on the use of accounting information in decision-making. It indicates that even a business may use accounting 
at the early stage of its operation due to its positive perception towards accounting information as well as the size of the business (number of employees). These results are similar to the study on Sri Lankan manufacturing sector (Kariyaisam, 2016).

Furthermore, the difference and interaction among firms (based on the number of employees and level of perception) in the use of ACI in decision-making, this research conducted a two-way ANOVA following Eq. (2). Based on the number of employees, the firms have been grouped into three categories, such as low (0-1), medium (2-4), and high ( $\geq 5)$ while based on perception the categories were low $\leq 5$, moderate (6-10), and high ( $\geq 11)$. It is important to note that this research used a cut off points to decide upon the groups. The findings of factorial ANOVA in Table 6 shows that there is a significant mean effect of the number of employees in firms $\mathrm{F}(2,95)=13.456, \mathrm{p}<0.01$ and perception $\mathrm{F}(2,95)=4.103, \mathrm{p}<0.05$ on the use of ACI in business decision-making.

Table 6: Two-way ANOVA showing effect of factors and their interaction (Eq. 3)

\begin{tabular}{lrrrrr}
\hline & $\begin{array}{c}\text { Sum } \\
\text { of Squares }\end{array}$ & df. & \multicolumn{1}{c}{$\begin{array}{c}\text { Mean } \\
\text { Square }\end{array}$} & \multicolumn{1}{c}{ F } & \multicolumn{1}{c}{ Sig. } \\
\hline Intercept & 36051.526 & 1 & 36051.526 & 498.586 & 0.000 \\
Number of employee & 1945.966 & 2 & 972.983 & 13.456 & 0.000 \\
$\begin{array}{l}\text { Perception } \\
\text { Number of employee* }\end{array}$ & 593.321 & 2 & 296.660 & 4.103 & 0.020 \\
perception & 928.991 & 4 & 232.248 & 3.212 & 0.016 \\
Error & 6869.218 & 95 & 72.308 & \multicolumn{1}{c}{-} \\
\hline $\begin{array}{l}\text { R Squared = 0.375 (Adjusted R Squared = 0.322), Dependent variable: Use of ACI in } \\
\text { business decision-making }\end{array}$
\end{tabular}

Games-Howell post hoc test revealed that the use of ACI for decision-making is similar for low and moderate perception group, $\mathrm{M}_{\mathrm{diff}}=-1.695 \% \mathrm{CI}[-6.28,3.08]$, $\mathrm{p}=0.692$. However, the use of ACI is significantly higher for high perception group compared to low perception group (Dobroszek et al., 2019), $\mathbf{M}_{\text {diff }}=7.5395 \%$ $\mathrm{CI}[1.08,13.99], \mathrm{p}<0.05$, while no significant difference is observed between high and moderate perception group, $\mathrm{M}_{\mathrm{diff}}=-5.93,95 \% \mathrm{CI}[-12.20,0.326], \mathrm{p}=0.067$. In case of number of employees, Games-Howell post hoc test showed that firms having medium, $\mathrm{M}_{\text {diff }}=9.38,95 \% \mathrm{CI}[4.95,13.82], \mathrm{p}<0.01$ and high number of employees, $\mathrm{M}_{\text {diff }}=10.97,95 \% \mathrm{CI}[5.66,16.28], \mathrm{p}<0.05$ had significantly higher use of ACI compared to low number of employees (Horvat \& Mojzer, 2019). However medium and high number of employee firms did not represent any significant difference, $\mathbf{M}_{\text {diff }}$ $=-1.58,95 \% \mathrm{CI}[-7.40,4.22], \mathrm{p}=0.790$ in the use of ACI for decision-making. Table 6 reveals that there is a significant interaction between the number of employees in firms and perception level on the use of $\mathrm{ACI}$ in business decision-making $\mathrm{F}(4,95)$ $=3.21, \mathrm{p}<0.05$. For further clarification, an interaction between perception and number of employees on the use of ACI for decision-making is presented in Figure 1. 
Perceived use of accounting information and practices of accounting in micro enterprises of developing countries

Figure 1. Interaction between number of employees and perception on the use of ACI for decision-making

Estimated Marginal Means of Use of $\mathrm{ACl}$ for decision making

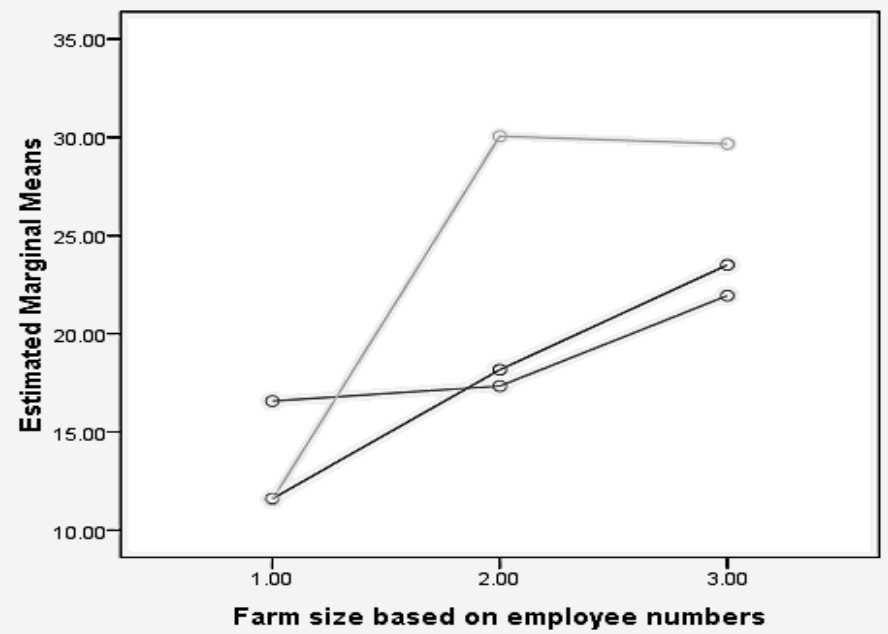

Peosprion
-1.00
-2.00
-3.00

Figure 1also shows that perception had effect on the use of ACI for decision-making for small and medium number of employees' firms, while for the firms having higher number of employees, perception don't represent any significant effect on the use of ACI for business decision-making.

\section{Current practices}

The observed current practices are ranked based on weighted mean of responses against each observed practice to have a preliminary understanding on the extent of accounting practices in the surveyed enterprises, which are presented in Table 7.

As presented in the methodology section, the observed current practices are analysed using PCR, in which principal component factor analysis (PCA) is used at first for reducing the dimensionality of the observed practices. The outputs of PCA are subsequently used in multivariate analysis along with characteristics for identifying the relationship of current practices with performance. 


\subsection{Status of current practices of accounting}

It is clear from Table 7 that MEs' existing accounting practices are predominantly rare, however, followed by few occasionally. Among the practices, cash reconciliation is mostly used as it ranks first with a weighted average of 2.07 followed by cash budget preparation (rank 2, mean 2.00), and budgeting (rank 3, mean 1.70). On the contrary, payroll journal preparation is practiced rarely as it ranks $18^{\text {th }}$ with the mean 0.70 , which seems justifiable, since most enterprises have very few or no hired employee(s). The reasons for more emphasize on cash and other related budgets may be that most of the surveyed enterprises are capital constrained. However, the details of accounting records are summarized, presented and reported in income statement, balance sheet, owner's equity statement and cash flow statement, which usually laid the foundation for useful decisions. Among these statements, respondents preferably prepared income statement (rank 7, mean 1.50); balance sheet (ranks 16, mean 0.95). On the other hand, respondents are aware about highly sensitive resource, cash. As a result, they maintained proper records for cash. Hence, it ranks one. In addition to these, Table 7 provides detail information on the use of other accounting practices. Overall, it seems that enterprises of the surveyed categories are practicing accounting based on their existing circumstances or needs, but not based on the regulatory requirements and not considering the benefits of set of accounting practices.

Table 7. MEs existing accounting practice summary $(n=105)$

\begin{tabular}{|c|c|c|c|c|c|c|c|}
\hline \multirow{2}{*}{ Current accounting practices } & \multicolumn{5}{|c|}{ Extent of practices } & \multirow{2}{*}{$\mathbf{W M}$} & \multirow{2}{*}{$\mathbf{R N}$} \\
\hline & $\mathbf{A L}$ & FR & OC & $\mathbf{R A}$ & NV & & \\
\hline Cash reconciliation & 34 & 15 & 12 & 12 & 32 & 2.07 & 1 \\
\hline Prepare cash budget & 23 & 26 & 14 & 12 & 30 & 2.00 & 2 \\
\hline Use of budgeting & 17 & 18 & 18 & 20 & 32 & 1.70 & 3 \\
\hline $\begin{array}{l}\text { Compare actual costs with the budget } \\
\text { limits }\end{array}$ & 8 & 21 & 23 & 30 & 23 & 1.63 & 4 \\
\hline Prepare revenue budgets & 14 & 19 & 22 & 14 & 37 & 1.61 & 5 \\
\hline Prepare expense budgets & 13 & 21 & 18 & 17 & 37 & 1.58 & 6 \\
\hline Prepare income statement & 14 & 25 & 8 & 11 & 47 & 1.50 & 7 \\
\hline Prepare cash receipts journal & 21 & 9 & 9 & 5 & 61 & 1.28 & 8 \\
\hline Prepare general ledger & 22 & 10 & 4 & 3 & 66 & 1.23 & 9 \\
\hline Prepare purchase journal & 17 & 9 & 10 & 10 & 59 & 1.19 & 10 \\
\hline Prepare financial statements & 11 & 11 & 12 & 24 & 48 & 1.18 & 11 \\
\hline Prepare sales journal & 21 & 6 & 7 & 5 & 66 & 1.15 & 12 \\
\hline Prepare accounts receivable ledger & 15 & 10 & 10 & 4 & 66 & 1.09 & 13 \\
\hline Prepare accounts payable ledger & 16 & 9 & 7 & 6 & 67 & 1.06 & 14 \\
\hline Prepare cash disbursement journal & 11 & 13 & 8 & 6 & 67 & 1.00 & 15 \\
\hline Prepare balance sheet & 14 & 8 & 6 & 9 & 69 & 0.95 & 16 \\
\hline Prepare owner's equity statement & 8 & 12 & 8 & 8 & 69 & 0.88 & 17 \\
\hline Prepare Payroll journal & 6 & 9 & 9 & 10 & 71 & 0.75 & 18 \\
\hline
\end{tabular}




\subsection{Relationship of accounting practices with performance}

To provide a deeper understanding on the current practices, the principal component extraction method in combination with the varimax rotation method has been applied. Using these methods, 18 observed practices are reduced into three (3)principal components renamed as "using only for record keeping", "using for planning, controlling and monitoring", and "using for performance measurement", which are shown in Table 8. An individual practice of accounting is assigned to a group based on its corresponding factor loading value (highest).These three broad practices have Eigen values exceeding 1.0 and total variance of $78 \%$. The applicability of factor analysis has been verified using the KMO test of sample adequacy and Bartlett's test of sphericity. The KMO measure of adequacy was 0.96 , and Bartlett's test of sphericity was statistically significant at 1\% (Table 4). All the tests indicated that PCA is a good fit for this dataset (Hair et al., 2006). Current practices having factor loadings above 0.50 are considered as important practice of accounting (Flaten et al. 2005).

Table 8. Varimax rotated factor loadings for current accounting practices

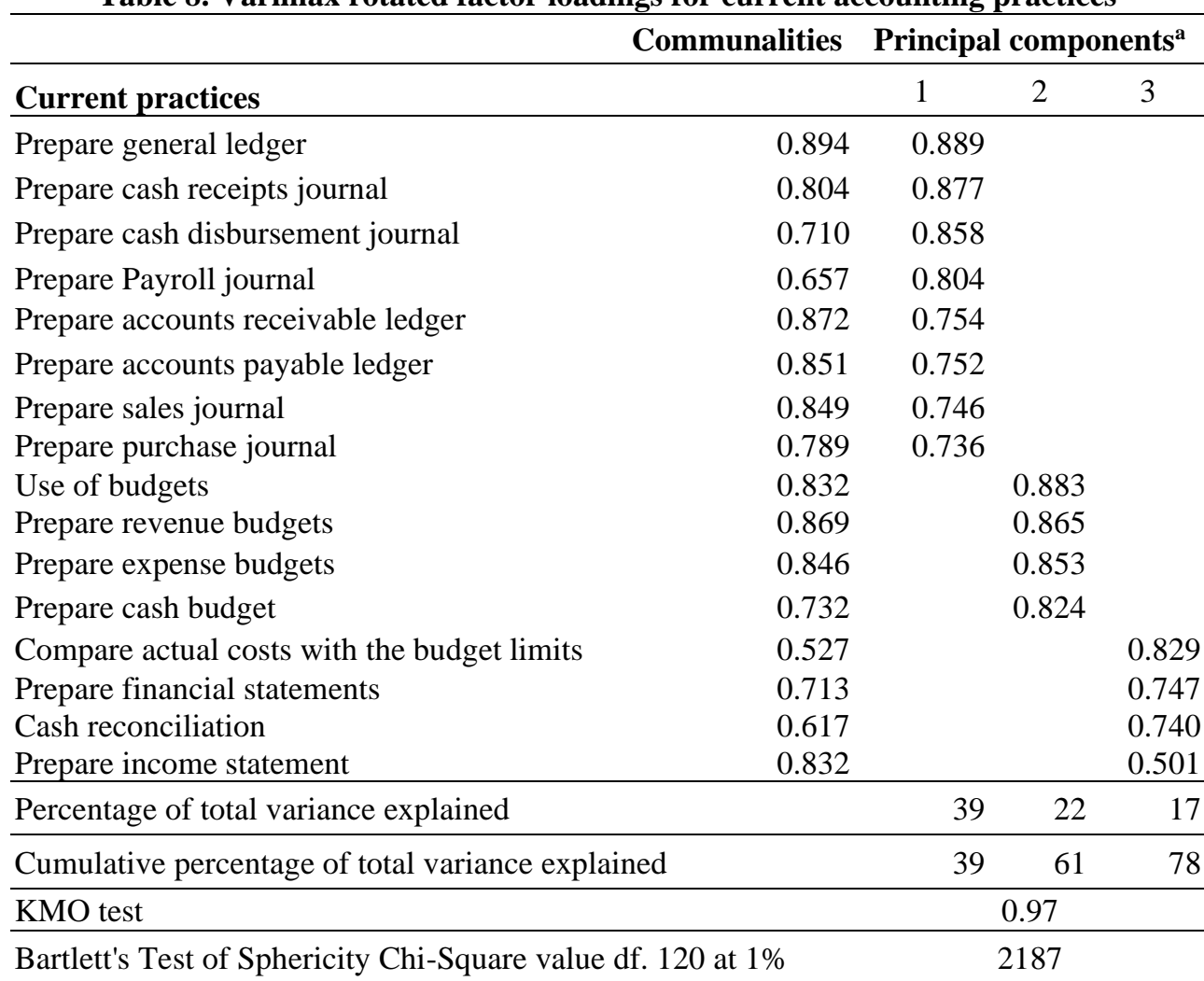

Principal components are, record keeping; planning, controlling and monitoring; and performance measurement. The categorizations are based on the factor loading (loadings > $0.50)$ of individual practices. 
The broad accounting practice categories (principal components) and characteristics of enterprises have been regressed against turnover to examine if the performances of the sampled enterprises are influenced by higher level of accounting practices. The estimated parameters are reported in Table 9, which reports $\mathrm{p}$ values and Variance Inflation Factor (VIF) to examine if particular parameters are statistically significant and if there is any multicolinearity. It has been found that the level of education of the owner, age of the business, size (number employees) of the business, nature of the business are statistically significant, indicating that all of these variables have statistically significant influence on increasing turnover of the business, hence the financial performance of the enterprises. On the other hand, all the three broad categories (i.e., using accounting for record keeping; planning, monitoring, and controlling; and performance measurement) have statistically significant impact on financial performance at $1 \%, 5 \%$ and $10 \%$ significance level respectively. Furthermore, there is no multicolinearity among the variables since all VIF values are less than 5 .

Overall, the results indicate that higher financial performance can be achieved if the micro enterprises can practice accounting system, which will also generate more revenues for the government and will support the credit worthiness of the entities. However, given the poor level practices of accounting, the accounting procedure should be made easier through training or providing manuals or formats specific to each category of business enabling the micro enterprises to follow standard accounting practices. It may also be possible by providing professional accounting services at lower costs to such entities. These findings support the findings of existing studies on SMEs such as Assaduzzaman (2016), which points out that the financial performance is higher in case of firms maintaining the accounting and financial records (Orobia et al., 2020 and Venter et al., 2018).

Table 9. Results of Multiple Regression for current practices of accounting Eq. (4)

\begin{tabular}{lrrr}
\hline & \multicolumn{1}{l}{ Beta } & P-values & \multicolumn{1}{l}{ VIF } \\
\hline Intercept & -384.918 & 0.007 & - \\
\hline Education (Year) & 0.241 & 0.007 & 1.197 \\
Business length (Year) & 0.202 & 0.015 & 1.039 \\
Number of employees & 0.405 & 0.000 & 1.571 \\
Merchandizing & 0.428 & 0.007 & 3.747 \\
Manufacturing & 0.257 & 0.089 & 3.502 \\
Accounting for record keeping & 0.220 & 0.009 & 1.065 \\
Accounting for planning, controlling and monitoring & 0.103 & 0.023 & 1.169 \\
Accounting for performance measurement & 0.015 & 0.090 & 1.260 \\
\hline
\end{tabular}




\section{Conclusion and recommendation}

Micro enterprises are the simplest form of business because of its ease of starting, low investment and notional regulatory requirements, which motivate entrepreneurs with low capital to start such business and can contribute to the economy significantly, especially in developing countries if managed efficiently. The success of such business also rests on using accounting information for useful decisionmaking. Considering very limited data sets from a limited geographical area, this research provided insights on understanding how the micro business organizations perceive the use of ACI in making business decisions and its current practices. The results of this study indicate that perceived use of $\mathrm{ACI}$ in decision-making in micro enterprises in developing countries is very low. The use of ACI in decision-making is largely shaped by the perception of the sole proprietors and the number of employees in the firm (i.e. size of the enterprises), which supports the findings of Mendoza (2014) and Ismail and King (2005). Furthermore, the most of the accounting practices are very rare in MEs except cash reconciliation and cash budget preparation.

However, higher practices are associated with higher performance of the enterprises. This finding supports existing literature stating that practices of accounting improve the financial performance irrespective of size and the economy in which the business operates (Ismail \& King, 2005; Orobia et al., 2020; Venter et al., 2018). In addition, this study has identified that the use of accounting for record keeping; for planning, controlling and monitoring; and for performance measurement have statistically significant influence on turnover, which imply that the financial performance is higher for enterprises which use accounting for these purposes. This finding is also in conformity with the earlier studies Dorasamy et al. (2010) and Kamyabi and Devi (2010).

The policy recommendation from this study is that it is important to introduce special policy, to encourage entrepreneurs in using ACI for business decision-making and train them on how to maintain accounting records, and eventually its usage to make business decisions. In addition, results imply that if practices of accounting can be improved, it may support more government revenue generation and the interested financial institutions (both government and non-government) will be able to offer credit priority, additional financial incentives, tax waiver, low interest rate lending, etc., for the firms exhibiting satisfactory level of performance.

Finding the causes of poor perceived use of accounting information in decisionmaking in micro enterprises in developing countries may be the focus for the future research. Furthermore, future research can be focused on how the practices of accounting be improved in these enterprises. 


\section{Funding and acknowledgement}

The authors are grateful to the Patuakhali Science and Technology University for funding the survey for this study and to the anonymous reviewers for their suggestions and comments that helped substantially to improve the paper.

\section{References}

Ademola, G. O., James, S. O. \& Olore, I. (2012) “The roles of record keeping in the survival and growth of small scale enterprises in Ijumu Local Government Area of Kogi State", Global Journal of Management and Business Research, vol. 12 , no. 13: 55-66

Akanbi T. A., Fashina, H. T. \& Aruwaji, M. A. (2017) “Owners' perception on accounting information system adoption: A case of small and medium enterprises in Nigeria", European center for research training and development, vol. 5, no. 11: 1-9

Alam, M. and Nandan, R. (2010) "Organisational change and innovation in small accounting practices: evidence from the field", Journal of Accounting \& Organizational Change, vol. 6, no. 5: 460-476

Albu, C.N., Albu, N. \& Street, D.L. (2016) "The Role of SMPs in providing business support to SMEs: New evidence", International Federation of Accountants (IFAC), https://www.ifac.org/publications-resources/role-smps-providingbusiness-support-smes-new-evidence.

Albu, C.N., Albu, N., Pali-Pista, S.F., Gîrbină, M.M., Selimoglu, S.K., Kovács, D.M., Lucacs, J., Mohl, G., Mullerova, L., Pasekova, M., Sipahi, B., Strouhal, J. \& Arsoy, P.A. (2013) "Implementation of IFRS for SMEs in emerging economies: Stakeholder perceptions in the Czech Republic, Hungary, Romania and Turkey", Journal of International Financial Management \& Accounting, vol. 24, no. 2: 140-175

Amoako, G.K. (2013) "Accounting practices of SMEs: A case study of Kumasi Metropolis in Ghana", International Journal of Business and Management, vol. 4, no. 4: 73-83

Andrianaivo, M., Skamnelos, I. \&Ndiaye, A. (2018) "Financing Solutions for Micro, Small, and Medium Enterprises in Bangladesh", The World Bank, vol.132967:1-64

Asaduzzaman, M. (2016) "Accounting and financial reporting practices of SMEs: Bangladesh perspective", Malaysian Journal of Business and Economics (MJBE), vol. 3, no. 1: 57-67

Aziz, T. \& Siddique, M. N. E.A. (2016) "The role of Bangladesh Bank in promoting SMEs' access to finance in Bangladesh", International Journal of SME Development, vol. 3, no. 2: 103-118

Blackburn, R. \& Jarvis, R. (2010) "The role of small and medium practices in providing business support to small- and medium-sized enterprises", A Report 
for the International Federation of Accountants, New York, NY, ISBN: 9781-60815-064-9: 1-32

Blackburn, R. \& Jarvis, R. (2010) "The role of small and medium practices in providing business support to small-and medium-sized enterprises", Small and Medium Practices Committee Information Paper, International Federation of Accountants, New York, NY

Blackburn, R., Carey, P. \& Tanewski, G. (2014) "Business Advice by Accountants to SMEs: Relationship and Trust", Proceedings of the Small Enterprise Association of Australia and New Zealand, 27th Annual SEAANZ Conference, Sydney, Australia, July, 16-18

Blackburn, R., Carey, P., \& Tanewski, G. (2018) "Business advice by accountants to SMEs: relationships and trust", Qualitative Research in Accounting \& Management, vol.15, no. 3: 358-384

Bosoteanu, M. C. (2016) "The use of accounting information in decision making: The case of Romania", Management \& Marketing Journal, vol. 14, no. 2: $349-360$

Botchway, H.B. \& Rashedi, H. (2018) "The perceptions of managers on the usefulness of accounting information during the decision-making process (Case Study: Iran Khodro Automotive Co)", Available at SSRN 3514157

Carey, P.J. (2015) "External accountants' business advice and SME performance", Pacific Accounting Review, vol. 27, no. 2: 166-188

Child, J., \& Hsieh, L. H. (2014) "Decision mode, information and network attachment in the internationalization of SMEs: A configurational and contingency analysis", Journal of World Business, vol. 49, no. 4: 598-610

Collier, P.M. (2015) Accounting for managers: Interpreting accounting information for decision making, John Wiley \& Sons

Copeland, R.M. and Dascher, P.E. (1978) Managerial accounting, John Wiley \& Sons, New York

Devi, S.S. \& Samujh, R.H. (2010) Accountants as Providers of Support and Advice to SMEs in Malaysia, ACCA Research Report no. 118, www.accaglobal.com/content/dam/acca/global/PDF-technical/smallbusiness/rr-118-001.pdf, accessed 4 April 2020.

Dlabay, L., Burrow, J. L. \& Kleindl, B. (2016) Principles of Business, Cengage Learning, Mason

Dobroszek, J., Zarzycka, E., Almasan, A. \& Circa, C. (2019) "Managers' perception of the management accounting information system in transition countries", Economic Research-Ekonomskaistraživanja, vol. 32, no.1: 2798-2817

Dorasamy, M., Marimuthu, M., Jayabalan, J., Raman, M. \& Kaliannan, M. (2010) Critical Factors in Outsourcing Of Accounting Functions In Malaysian Small Medium-Sized Enterprises (SMEs), Journal of Malaysian Studies, vol. 28, no. 2: 39-69

Drucker, P.F. (2010) The frontiers of management: Where tomorrow's decisions are being shaped today, Harvard Business Review Press.

Ezejiofor, R.A. \& Olise, M.C. (2014) "The relevance of accounting records in small scale business: The Nigerian experience", International Journal of Academic Research in Business and Social Sciences, vol. 4, no. 12: 69-82 
Faraway, J.J. (2002) Practical regression and ANOVA using $R$ (Vol. 168, Bath: University of Bath.

Flaten, O., Lien, G., Koesling, M., Valle, P. S. \& Ebbesvik, M. (2005) “Comparing risk perceptions and risk management in organic and conventional dairy farming: Empirical results from Norway", Livestock Production Science, vol. 95, no. 1-2: 11-25

Grazia-Oana, P. (2012) "The role of accounting information in the decision making process", Economic Sciences Series, vol. XII, no. I: 1594-1598

Hair, J., Anderson, J.F., Tatham, R. E., \& Black. W. C. (2006) Multivariate data analysis, Upper Saddle River, NJ: Prentice-Hall.

Hiebl, M. R. W. (2013) "Bean counter or strategist? Differences in the role of the CFO in family and non-family businesses", Journal of Family Business Strategy, vol. 4, no. 2: 147-161

Horvat, T. \& Mojzer, J. (2019) "Influence of company size on accounting information for decision-making of management", Našegospodarstvo/Our economy, vol. 65 , no. 2 : $11-20$

Institute of Chartered Accountants in England and Wales (ICAEW) (2014) The 99.9\%: Small and Medium-Sized Businesses. Who Are They and What Do They Need?, ICAEW, UK

Ismail, N.A. and King, M. (2005) "Firm performance and AIS alignment in Malaysian SMEs", International Journal of Accounting Information Systems, vol. 6, no. 4: 241-259

Ismail, N.A., Abdullah, S.N. \& Tayib, M. (2003) "Computer-based accounting systems: the case of manufacturing-based small and medium enterprises in the Northern Region of Peninsular Malaysia”, Journal Technology, vol. 39, no. 1: 19-36

Jesmin, R. (2009) "Financing the small scale industries in Bangladesh: the muchtalked about, but less implemented issue", Proceedings of American Society of Business and Behavioral Sciences, vol. 16, no. 1: 1-13

Kahsay, G. \& Zeleke, G. (2019) "Factors Affecting use of accounting records on small \& micro enterprises (the Case of DebreBirhan City, Ethiopia)", Journal of Investment and Management, vol. 8, no. 1: 1-7

Kamyabi, Y. \& Devi, S. (2011) "Use of professional accountants' advisory services and its impact on SME Performance in an emerging economy: a resourcebased view", Journal of Management and Sustainability, vol. 1, no. 1: 43-55

Kariyaisam, H. (2016) "Relationship between Accounting Information and Decision Making in the Sri Lankan Manufacturing Sector", International Journal of Business and Management Invention, vol. 5, no.12: 1-5

Kieso, D.E., Weygandt, J.J. \& Warfield, T.D. (2011) Intermediate Accounting, Problem Solving Survival Guide (Vol. 1), John Wiley \& Sons

Lalin, H. \& Sabir, R.I. (2004) "Research on usage and usefulness perception of financial accounting practices in a less developing country: A case of SMEs in Cambodia", International Conference on Innovation \& Management, Proceedings of the 7th International Conference on Innovation \& Management: 1881-1885 
Lien, G., Flaten, O., Jervell, A.M., Ebbesvik, M., Koesling, M. \& Valle, P.S. (2006) "Management and risk characteristics of part-time and full-time farmers in Norway", Review of Agricultural Economics vol. 28, no. 1: 111-131

Lind, D. A., Marchal, W. G. \& Wathen, S. A. (2010) Statistical Techniques in Business and Economics (14 ${ }^{\text {th }}$ ed.), Irwin: McGraw Hill

Lucas, M., Prowle, M. \& Lowth, G. (2013) "Improving SME performance through management accounting education", Management Accounting Practices of UK Small-Medium-Sized Enterprises, vol. 9, no. 4: 1-14

Maseko, N. \& Manyani, O. (2011) "Accounting practices of SMEs in Zimbabwe: An investigative study of record keeping for performance measurement (A case study of Bindura)", Journal of accounting and taxation, vol. 3, no. 8: 171-181

Mbroh, J.K. \& Assah, B. (2015) "Financial Records Keeping and Business DecisionMaking Practices by Small and Micro Enterprise Owners in Ghana-Evidence from the Central Region", International Journal of Economics, Commerce and Management, vol. 3, no. 8: 467-491

Mendoza, R. R. (2014) "Accountancy service requirements of micro, small, and medium enterprises in the Philippines", International Journal of Business, Economics and Law, vol. 4, no.1:123-132

Mitchell, F., Reid, G. \& Smith, J. (2000) Information system development in the small firm: The use of management accounting", London: CIMA Publishing

Muteti, N., Namusonge, M. \& Nzomo, D. (2018) “Accounting Systems for Records Keeping Practices for Small Enterprise Development in Makueni County, Kenya", Open Journal of Accounting, vol.7, no. 3:181-190

Nanyondo, M. (2013) "Quality of financial statements, information asymmetry perceived risk, and access to finance: A study of Small and Medium Enterprises in Kampala District", Doctoral dissertation, Makerere University

Ndiaye, N., Razak, L.A., Nagayev, R. and Ng, A. (2018) "Demystifying small and medium enterprises' (SMEs) performance in emerging and developing economies", Borsa Istanbul Review, vol. 18, no. 4: 269-281

Obasan, K.A., Shobayo, P.B. \& Amaghionyeodiwe, A.L. (2016) "Ownership structure and the performance of small and medium enterprises in Nigeria", International Journal of Research in Social Sciences, vol. 6, no. 9: 474-492

Okoli, B.E. (2011) "Evaluation of the accounting systems used by small scale enterprises in Nigeria: The case of Enugu-South East Nigeria", Asian Journal of Business Management, vol. 3, no. 4: 235-240

Orobia, L.A., Nakibuuka, J., Bananuka, J. \& Akisimire, R. (2020) "Inventory management, managerial competence and financial performance of small businesses", Journal of Accounting in Emerging Economies, vol. 10, no. 3: 379-398

Padachi, K. (2012) "Factors affecting the adoption of formal accounting systems by SMEs", Business and Economics Journal, vol. BFJ-67: 1-21

Perren, L. \& Grant, P. (2000) "The evolution of management accounting routines in small businesses: A social constructive perspective", Management Accounting Research, vol. 11, no. 4: 391-411 
Phellas, C.N., Bloch, A. \& Seale, C. (2011) "Structured methods: interviews, questionnaires and observation", Researching Society and Culture, vol. 3: 181-205

Royaee, R., Salehi, A. \& Aseman, H.S. (2012) "Does accounting play a significant role in managerial decision-making?", Research Journal of Business Management and Accounting, vol. 1, no. 4: 57-63

Sawers, D. \& Whiting, R.H. (2010) "Perceived usefulness of business succession planning and chartered accountants' involvement in the process", Small Enterprise Research, vol. 17, no. 1: 87-102

Seman, N.A. A., Jusoh, N.A.Q., Rashid, U.K. \& Ramin, A.K. (2019) "An analysis of basic accounting practices of microenterprises", International Journal of Engineering and Advanced Technology, vol. 5, no. 5C: 628-637

Siyanbola, T.T. (2012) "Accounting information as an aid to management decision making”, International Journal of Management and Social Sciences Research (IJMSSR), vol. 1, no. 3: 29-34

Soininen, J., Martikainen, M., Puumalainen, K. \& Kyläheiko, K. (2012) "Entrepreneurial orientation: Growth and profitability of Finnish small-and medium-sized enterprises", International Journal of Production Economics, vol. 140 , no. 2: 614-621

Songini, L., Gnan, L. \& Malmi, T. (2013) "The role and impact of accounting in family business", Journal of Family Business Strategy, vol. 4, no. 2: 71-83

Stone, G.W. (2011) "Readability of accountants' communications with small business - Some Australian evidence", Accounting Forum, vol. 35, no. 4: 247261

Uddin, R., Biswas, T., Ali, J. \& Khatun, M.S. (2017) “Accounting practices of small and medium enterprises in Rangpur, Bangladesh, Journal of Business and Financial Affairs, vol. 6, no. 4: 1-7

Venter, E.R., Gordon, E.A. \& Street, D.L. (2018) "The role of accounting and the accountancy profession in economic development: A research agenda", Journal of International Financial Management \& Accounting, vol. 29, no. 2: 195-218

Williams, J. R., Haka, S. F., Bettner, M. S. \&Carcello, J. V. (2008) Financial and managerial accounting, NY: Mc Graw-Hill Irwin

${ }^{i}$ The formula for the KMO test is given by:

$$
K M O_{j}=\frac{\sum r_{i j_{i \neq j}^{2}}}{\sum r_{i j}^{2}+\sum u_{i \neq j}},
$$

where, $r_{i j}$ is the correlation martrix, and $u_{i j}$ is the partial covariance matrix 